But the CNR, undeterred by these drawbacks and alarmed by the prospect of a ministry, is having another go at applied research. In 1972, after consulting researchers and the Office for Economic Development, it put forward 78 proposals for research projects with potential economic or social applications. By the beginning of 1975 an initial selection had reduced the number of projects to about 40 , grouped into seven themes: energy (eg. solar and geothermal energy, conservation of energy); food (eg. increasing plant productivity, new sources of protein, mechanisation of agriculture, fisheries research); health (eg. preventative medicine, viruses, reproduction, biomedical technology); environment (eg. geodynamics, oceanography, soil conservation); educational theory; advanced technology (eg. telecommunications with centimetre and millimetre waves, power lasers, superconductivity, ceramics, control of air traffic); and cognitive advancement (a ragbag including criminology and astrophysics).

These projects, together with assessments of their feasibility and usefulness, were submitted to the CIPE in April 1975. The CIPE's ruling, published on October 9, was startling. The entire 'Health' programme and almost all of 'Food' were approved. 'Energy' and 'Environment' were heavily lopped; nothing remained, for example, of the projects on solar and geothermal energy. 'Cognitive Advancement' and 'Educational Theory' were rejected, at least for the present. But most surprising, after all the trumpeting about the economic needs of the country, 'Advanced Technology' was almost completely rejected: only the project on the control of air traffic remains.

It is possible that the government has simply lost faith in the CNR's ability to know what industry needs, and prefers to wait for the Ministry for Research. This might be deduced from the extremely fuzzy explanations the CIPE report gives for its decisions. Perhaps the CIPE is concerned to prevent toes from being trodden on-the National Electricity Board (ENEL), for example, may consider research into new sources of energy its own preserve. It may also be considering the violent public dislike of multinationals, which could see the research on telecommunications, for example, as somehow pandering to the Americans.

In any case about 20,000 million lire have been set aside for the first year's research on those projects which have survived scrutiny. Owing to administrative delays it will not actually be handed out until towards the end of this year. The CNR's 1975 grant of 83,000 million lire is increased this year to 100,000 million lire, which means 3,000 million lire less for other research of the CNR - a blow at any time but especially with inflation.

Will the success of the applied projects make the loss worthwhile? Unfortunately the answer is likely to be no. The projects suffer from the defect seen in all CNR funding, which is ultimately the fault of the way Italian universities are organised. Substantial amounts of money are divided into too many little sums, with the result that there is much duplication and nobody has the resources for a major piece of work. The practice arises because Italian universities are divided into small faculties, usually with one full professor each, which jealously maintain the barriers between themselves and other faculties. The CNR has naturally never challenged this arrangement, and nothing has changed with the new applied projects: only one quarter of the money is going to CNR institutions, some at least of which are big enough for a more flexible, interdisciplinary approach; most of the rest is destined for hundreds of university faculties.

Given this, and the fact that little thought seems to have been directed at precisely how the results achieved are to be made available to those who might use them, the projects seem likely to cause little more than a ripple in Italian economic or social life. But one thing to be thankful for is that the money is there to do something with. If a large part of it ends up financing the pure research that the academics really want to do, many would say so much the better. But when the Ministry for Research is created, money for pure research may be difficult to come by.

\title{
Getting the message across
}

\author{
David Spurgeon reports from Ottawa on \\ science and the mass media in Canada
}

A STUDY on communication of science through the mass media confirms what Canadian scientists, science writers and ordinary readers have known for a long time: that the Canadian media do an inadequate job of making science meaningful to their public. But, surprisingly to some, it also indicates that a far greater public desire exists for science coverage than most media managers seem to realise.

The study, begun in 1973, was published recently by the Canadian

* Media Impact, Volume 2, Science, Mass Media and the Public, A Research Study on Science Communication. By Orest Dubas and Lisa Martel (Information Canada; June 1975).
Ministry of State for Science and Technology (MOSST)*. It indicates, for example, that science writers are willing and anxious to do a better job, but that they are hindered by the out-dated ideas and prejudices of their bossesthose who control what the media transmit to the public. At the same time, it reveals that much of the general public is just as interested in learning about science as about those other human activities that receive preferential treatment by the media; yet because of the attitudes of the media managers, this desire goes unsatisfied. The study shows how great the need is for better science coverage, for it reveals the abysmal ignorance about Canadian science on the part of those

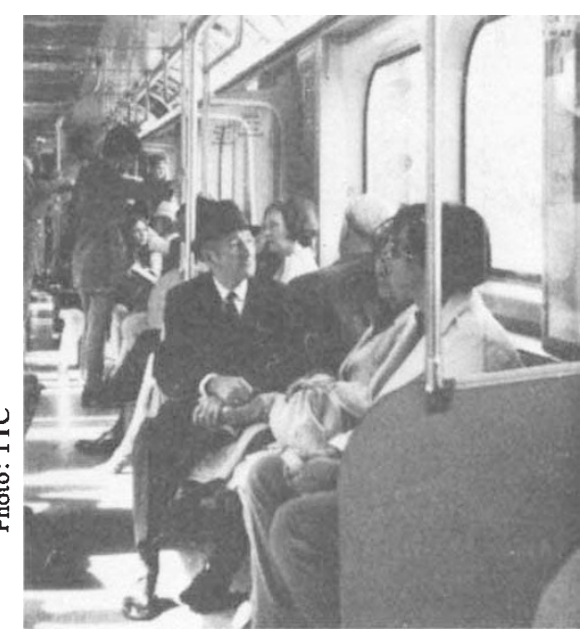

Toronto Transit commuters: does the Canadian public at large get the science coverage it wants?

same members of the public who want to know more.

The results contained in the second volume, released to the public last month, are the outcome of three separate surveys made of managing 
editors of daily newspapers with a circulation of more than 5,000, science writers and the public at large. Volume 1 contained an outline of objectives and methodology and gave an account of past research on science communication in other countries.

The public survey was conducted between March and April 1974 by the private firm, Canadian Facts: 2,000 Canadians, aged 15 and over, were randomly selected for interview. The surveys of managing editors and science writers were conducted by the authors through questionnaires. Editors of 52 of the 81 newspapers polled responded. From 176 writers (only 24 of them employed to write science or medicine full-time for daily newspapers) 113 replies were received.

Some indication of the general level of awareness of science affairs in Canada can be gained from the finding that two out of three people interviewed could not even name a single scientist. Of those who did recall one or more names, less than one in five could name more than two. And when names were mentioned, they were mostly the expected ones: Frederick Banting and Charles Best, co-discoverers of insulin, were mentioned about half the time, and-American claims for the invention of the telephone to the contraryAlexander Graham Bell was mentioned by another third. Only seven persons among the 2,000 polled could recall the name of $\mathrm{Dr}$ Gerhard Herzberg. the physicist who won Canada's only Nobel Prize in the natural sciences almost half a century after Banting. Best and MacLeod were awarded the country's only Nobel Prize in medicine in 1923.

To make things worse, some of those interviewed tended to confuse Canadian scientists with those of other countries. or even with public figures who were not scientists at all. For example. $7 \%$ cited names like Albert Einstein. Louis Pasteur, Eve Curie, Charles Darwin, Jonas Salk and Alexander Fleming when asked for names of Canadian scientists. And occasinnallv they brought up names like Lester Pearson (former prime minister). Mme Jeanne Sauvé (former science minister). Farley Mowat (a writer on nature themes), and Fernand Seguin (a French Canadian science communicator).

When it came to Canadian scientific arhievements. $61 \%$ failed to name one, $22.8 \%$ listed a single achievement, $9.7 \%$ mentioned two and $8.1 \%$ three or more. The discovery of insulin and the invention of the telephone were remembered as Canada's greatest scientific achievements. and most of the optional "projects" mentioned were, really technological or engineering feats. such as the St. Lawrence Seawav or the Mirabel airport. Fewer than a dozen mentioned the CANDU nuclear power reactor, one of the most successful designs in the world. Many of those who recalled a Canadian scientific achievement did so because they were personally involved in it, or knew somebody who was. Thus insulin, for example, was remembered because a respondent "knew the first people treated", and a heart machine because they "used it on me at the hospital."

Significantly for the purposes of the study, the mass media appear to be the major source of what little public awareness there is of Canadian science. Nearly half the respondents cited the media as their major source of information. Magazines were the main source for science news, and were preferred over newspapers and television. Radio ran a poor third, which was surprising because the State-subsidised Canadian Broadcasting Corporation provides many good science programmes; more than half the respondents, however, said they were not aware of any of the science or public affairs programmes mentioned to them. Despite their evident ignorance of the subiect, $82 \%$ felt it was important to be kept informed about science, $63 \%$ were interested in finding out more about Canadian achievements, and more respondents than not (42.8 to $39.6 \%$ ) thought the media were providing an adequate coverage of science.

Furthermore, without being told that the interview focused on science, the public sample rated news of science and medicine high compared with news about such other things as sport. entertainment, society. politics and foreign affairs. Medicine and health ranked third in interest after news and education, and pollution and biology rated higher than entertainment. More indicated an interest in research in the physical sciences than in sports. Crime was third last on the list of 23 items of interest. following only after a number of scientific categories. And the public even declared itself willing to give up some coverage of some of the non-scientific categories in order to learn more about science.

To anyone who has written for the public about science for years, in fact, many of the public's responses as indicated by the survey were hard to believe. One obvious weakness of the survey was the breadth of its definition of science: it included not only the natural sciences. life sciences and engineering, but also the social sciences and even the humanities, under which such tonics as education, business and economics were listed. And one apnarent anomalv was the finding that less than half the interested readers judged science articles in newspapers to be accurately reported. In view of their obvious ignorance of the subject, how would they know? Three out of five, on the other hand, believed magazine articles (at least those about life sciences) to be well reported, and two out of three felt television reporting was accurate-in fact, television was perceived as the most accurate of the media, despite the fact that few magazines or television stations in Canada employ science specialists.

\section{The Communicators}

The study's survey showed that the science writers - the people initially responsible for communicating news of science-themselves believe that the media cover science inadequately, both in quantity and quality. They, too, judged the poorest medium to be radio (which, outside of the CBC, also employs few science specialists). They felt that one of the most important obstacles they faced in reporting science was the need to cover such a wide range of topics (more than one in three wrote on at least 10 fields of science a year), but they also pointed to the difficulty in keeping stories at once simple and accurate, and the lack of time they had to research their stories. The biggest external obstacle was the traditional reluctance of scientists to communicate with the public.

A profile of the science writers revealed that $69 \%$ had a university degree. but that twice as many had training in writing and the liberal arts as in the sciences. About $40 \%$ took either supplementary training or university courses in the sciences.

The managing editors survey showed less enthusiasm for science coverage and more complacency about the way it was currently being covered than either the public or the science writers. As the authors of the study summarised it: "Editors' replies (to a section asking if they anticipated changes) were indicative of management views on most papers: that all was well with science coverage." While nearly half the papers surveyed had assigned reporters to cover medicine and health. onlv $22 \%$ (11 papers) had assigned a staff member to cover science. Five of these science reporters were on papers with circulations of more than 75,000 . A variety of reasons were offered for not having a full-time science writer. Many editors said they could not afford it or found it cheaper to get the news from the wire services. And 29 of 33 editors who replied said their papers did not have enough staffwritten science news to justify a fulltime science writer-a neatly circular argument, as one critic put it.

Although both the public and the science writers who were surveyed thought it was a good idea to set up science news in a regular, easily-identi- 
fied way, the editors were less enthusiastic. Between 40 and $49 \%$ of the public agreed that, when they are specifically looking for science articles in the press, they have difficulty finding them. About $68 \%$ of the science writers would like to see a weekly column on science in the press, and $44 \%$ preferred a full page weekly devoted to science. Yet among the editors, only $31 \%$ believed readers would like to see some sort of regular science feature; $70 \%$ felt that science should be presented only as items became available, and only five of 52 editors thought readers would want a full page weekly.

Perhaps some clue can be found in the educational backgrounds of the editors: less than one in three had any science courses at the post-secondary school level, and only $31 \%$ had a university degree (compared with $69 \%$ of the science writers). Although $20 \%$ of the editors reported they had had science or technical writing experience themselves, it ranged from one whose cxperience was "sporadic" to three with more than 20 years' experience.

The authors of the study draw the following conclusions:

"There is as yet a dilettante, hit-andmiss approach to science coverage in general, and Canadian science in particular. Even the barest informative functions of the press are not met in this area, let alone the intcrpretive or educative role (which is becoming more important as science affects the readers more and more).

"Often only the highlights of a scientific meeting or the outline of a project-with little relevance to impact on society are presented; in many cases by news services reporters and not by staff writers of the paper... Finally, even if good stories are written, they can still get postponed or not even used-frequently superceded by the most trivial, sensationalized items; or else buried in the paper where only the hardy will ever find them."

However, like good journalists, the authors did at least give something of the other side of the argument. One of the editors quoted, from a paper of approximately 50,000 circulation in the prairie provinces, commented: "The whole tenor of the questionnaire is so unrelated to newsroom practice that answers cannot have any validity. For example, anyone knows that any particular story has 100 facets, and to attempt to departmentalize 'science' in the modern world is meaningless. And while on any one day, no one may edit what you call a 'science' story, the next day 10 people may deal with 15 socalled 'science' stories. Go into the newsrooms and you'll find your answers. First of all, define 'science' news."

\section{BRITISH STEEI}

\section{Quiet change at BSC}

Although the spearhead of the British Steel Corporation's attempts to stem its losses and revitalise itself depend to a great extent on agreement with the trade unions to a reduction in the total labour force (some 220,000 people at present), a step forward in rationalising its research and development was taken recently with the minimum of fanfare and publicity. Quite simply, the BSC now has a Chief Scientist and a Controller of $\mathrm{R}$ and $\mathrm{D}$, in the true Rothschild tradition of the "customercontractor principle"

The annual research budget of some $£ 13$ million may not seem much by comparison with the corporation's losses, which are now running at about $£ 8$ million a week, but when the BSC is properly on its feet again, it will undoubtedly profit from the more razor-cdged research arrangements that now seem in prospect.

As from the beginning of last December, Dr Robert S. Barnes, until then Director, Research and Development, became Chief Scientist, and $\mathrm{Mr}$ James Mackenzie, who had been Technical Director of the General Steels Division, became Director, Research Laboratories. This means, essentially, that Dr Barnes says what he wants done and $\mathrm{Mr}$ Mackenzie establishes that it can be done and sees that the work is carried out.

At present the two men are sizing their new jobs up and it will be a few months before they finally sort out precisely how their responsibilities should be divided. It is fairly certain, for example, that Dr Barnes will have under him a team which will be responsible for investigations into the cost-benefit of research done by the $\mathrm{BSC}$ and for techno-economic analysis. Until December, research was carried on within the corporation's four divisions and at three "corporate laboratories" which used to make up the old British Iron and Steel Research Association, BISRA. This somewhat decentralised system has its roots back in the days hefore British Steel was nationalised, and it is no secret that there has been some overlap and duplication of work, which admittedly has been decreasing over the years.

The corporation has no plans to close any of the laboratories or to cut its spending on research, and any redundancies that may occur will be part and parcel of the BSC's overall labour strategy. The changes do mean, however, that laboratories will lose some of their autonomy under $\mathrm{Mr} \mathrm{Mac}$ kenzie, who will be based in Teesside in North-east England. And there seems little chance of major new re search avenues being funded with new money in view of the corporation's perilous financial situation.

These changes in research and development do little, of course, to help the corporation with its immediate problem of turning itself into a viable entity. Since nationalisation in 1967 , BSC's capacity of some 27 million tonnes a year has been maintained while the number of individual steel plants has been reduced from 40 to 30 , and the corporation's basic aim is to produce some $80 \%$ of a projected output of 35-37 million tonnes (in the mid-1980s) in just five major integrated steel complexes--two in Wales producing 9.5 million tonnes a year between them, two in North-east England with a combined output of 16 million tonnes and a Scottish complex (4 million tonnes). In these giant plants, ore will be turned into a finished product on a single site. The remaining $20 \%$ of the output will be mainly of special steels, and this activity will, as at present, be centred on Sheffield.

Up-to-the-minute though this may sound, BSC will be doing no more than the Japanese and others have already achieved: the Nippon Steel plant at Fukayama, for example, has an annual output of some 16 million tonnes, and that at Dunkirk in France produces about 8 million tonnes a year. It is widely agreed that a really viable steel plant must be sited near a deep-water terminal (thus eliminating the relatively very high cost of transporting ore by rail) and should have an output of several million tonnes a year (thus opening up the advantages of ore transportation in 250,000 -ton bulk carriers).

\section{Roger Woodham}

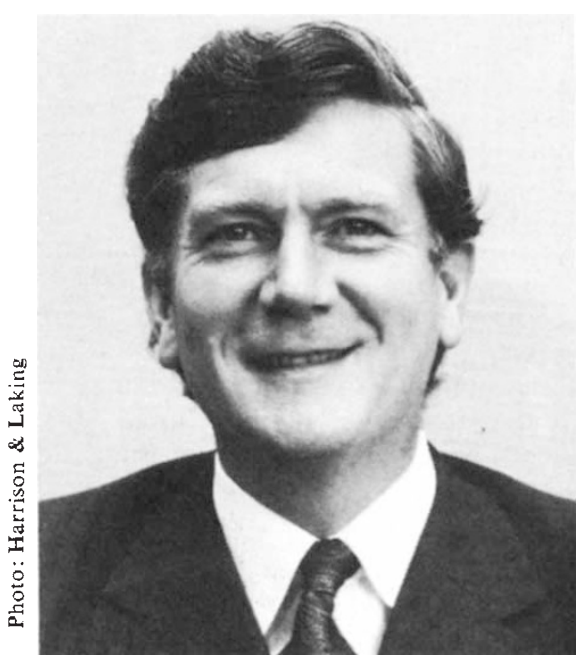

Robert Barnes, Chief Scientist at BSC. 